Pharmacotherapy. 2008 September ; 28(9): 1084-1097. doi:10.1592/phco.28.9.1084.

\title{
Warfarin Pharmacogenetics
}

\author{
NA Limdi ${ }^{1}$ and DL Veenstra ${ }^{2}$ \\ ${ }^{1}$ Department of Neurology, University of Alabama at Birmingham \\ ${ }^{2}$ Department of Pharmaceutical Outcomes Research and Policy Program and Institute for Public \\ Health Genetics, University of Washington
}

\section{Summary}

There has been significant interest in the pharmacogenetics of warfarin therapy with the recent package insert update highlighting its potential role in improving the safety and effectiveness of warfarin. Herein we review the evidence of the influence of the two key genes of interest, CYP2C9 and $V K O R C l$, on warfarin response, and discuss the implications of current knowledge for clinical practice.

The influence of $C Y P 2 C 9$ and $V K O R C 1$ genotype on warfarin dose requirements has been consistently demonstrated in diverse racial/ ethnic patient groups in observational studies and randomized clinical trails. Dosing algorithms have been developed that incorporate clinical, demographic, and genetic information to help select a starting warfarin dose. Furthermore, CYP2C9 variant genotypes have been associated with a significantly increased risk of serious bleeding events.

However evidence to date from prospective, controlled studies has not demonstrated an added benefit of incorporating genotype-guided therapy in improving anticoagulation control, preventing or reducing the risk of hemorrhagic or thromboembolic complications. Research efforts designed to evaluate the effectiveness of genotype-guided therapy in improving outcomes are underway. However the routine use of $C Y P 2 C 9$ and VKORC1 genotyping in the general patient population initiating warfarin therapy is not supported by evidence currently available.

\section{Keywords}

Warfarin; Pharmacogenetics; Cytochrome P4502C9; Vitamin K epoxide reductase

\section{Introduction}

Sixty six years since its discovery and fifty-four years since its commercial introduction in 1954, warfarin remains the mainstay of oral anticoagulant therapy. ${ }^{1,2}$ Despite proven efficacy, refinements and standardization in the monitoring of warfarin, its underutilization is widespread. ${ }^{3-6}$

What is clear is that the capricious nature of the response to any given dose of warfarin demands sophisticated and resource intensive methods to determine the warfarin dose and maintain therapeutic anticoagulation. The intricacies of warfarin metabolism, the complexities of the coagulation system and the multitude of factors affecting level of anticoagulation do not make this a straight forward task. Despite concerted efforts, development of dosing nomograms and

Corresponding Author: Nita A. Limdi, Pharm.D, PhD, MSPH, Department of Neurology, University of Alabama at Birmingham, 1719 $6^{\text {th }}$ Avenue South, CIRC-312, Birmingham AL 35294-0021, Email: nlimdi@uab.edu, Phone: (205) 934-4385. 
institution of specialized anticoagulation clinics, anticoagulation management is far from optimal.

The evolution of our understanding of warfarin pharmacodynamics and pharmacokinetics and the recognition of genetic regulation of warfarin response has stimulated efforts aimed at quantifying this influence. Although investigations have identified the influence of several genes on warfarin response, ${ }^{7}$ the bulk of the evidence supports the influence polymorphisms in two genes; Cytochrome P450 2C9 (CYP2C9) and Vitamin K epoxide reductase complex 1 ( $V K O R C 1)$. This evidence provided the basis for the recent warfarin package insert update (http://www.fda.gov/cder/drug/infopage/warfarin/default.htm) by the United States Food and Drug Administration (FDA).

The purpose of this manuscript is to provide an understanding of the role of $C Y P 2 C 9$ and $V K O R C 1$ in warfarin pharmacokinetics and pharmacodynamics, review the evidence of the influence of $C Y P 2 C 9$ and $V K O R C 1$ on warfarin response, and discuss the implications of current knowledge for clinical practice.

\section{The role of CYP2C9 and VKORC1 in warfarin pharmacokinetics and pharmacodynamics \\ Warfarin Pharmacokinetics}

Warfarin is administered as a racemic mixture of $(\mathrm{S})$ and $(\mathrm{R})$ warfarin. The enantiomers are extensively metabolized via distinct cytochrome P450 enzymes (Figure 1) with CYP2C9 serving as the principal enzyme in S-warfarin metabolism and CYP2C8,CYP2C18, $C Y P 2 C 19$ serving as minor pathways. R-warfarin is mainly metabolized by $C Y P 1 A 2$ and $C Y P 3 A 4$ with $C Y P 1 A 1, C Y P 2 C 8, C Y P 2 C 18, C Y P 2 C 19$ and $C Y P 3 A 4 / 5$ serving as minor pathways. ${ }^{8,9}$ The variable metabolism of the more potent $(\mathrm{S})$ enantiomer is responsible for the large variability in warfarin dose requirements. ${ }^{10}$

\section{Warfarin Pharmacodynamics}

Warfarin produces its pharmacological effect by interfering with the synthesis of vitamin K dependent clotting factors via inhibition of vitamin $\mathrm{K}$ epoxide reductase complex 1 (VKORC1). ${ }^{11,12}$ This interferes with the post-translational gamma-carboxylation of glutamic acid residues on coagulation factors II, VII, IX, and X, as well as the anticoagulant proteins C, $\mathrm{S}$, and $\mathrm{Z}$ by gamma-glutamyl carboxylase $(G G C X)$. Depletion of reduced vitamin $\mathrm{K}$ leads to the production of nonfunctional coagulation factors, producing anticoagulation (Figure 1).

Various research studies have implicated other genes in the variability of warfarin dosing in some patient populations. These include $G G C X,{ }^{13-16}$ clotting factors (protein C, Factor II and Factor VII), ${ }^{17}$ genes involved in transporting vitamin $\mathrm{K}$ warfarin including apolipoprotein $\mathrm{E}$ 18-20 and P-glycoprotein, ${ }^{21}$ and additional genes involved in vitamin K-epoxide metabolism. 14,22 16 While other genes and their encoded proteins may influence the inter-individual variability in warfarin response, the evidence is currently limited and are not discussed in this review.

\section{Challenges in assessing the evidence for the influence of CYP2C9 and VKORC1 on warfarin response}

Evaluating the relationship between variation in $C Y P 2 C 9 / V K O R C 1$ and warfarin-related outcomes can be particularly challenging due to the varying study designs, differences in outcomes evaluated, variation in outcome definitions and pharmacokinetic differences in 
coumarin anticoagulants used by participants. Therefore the reader should evaluate potential sources of error (chance, bias and confounding). Specifically, the reader should:

- Understand the strengths and limitations of various observational study designs (retrospective versus prospective; case-control versus cohort, comparative intervention trial versus association study) in addressing the hypothesis of primary interest.

- Be vigilant of eligibility criteria. For example did recruitment target patients with certain indications, duration of therapy or patients who met certain criteria (e.g. on stable warfarin dose).

- Appreciate differences in duration of the study follow-up and type of data; longitudinal (over time) or cross-sectional (a single point in time).

- Be familiar the measurement and adjustment for confounding variables such as comorbid conditions, dietary vitamin $\mathrm{K}$ intake, concomitant medications, etc.

- Understand genotyping methodology and its validity

- Understand how the outcome is defined and measured. For example:

- Warfarin dose: Stable dose or average maintenance dose

- Over-anticoagulation : INR $>4$ or $>6$ ?

- Hemorrhage: Were major and minor bleeding complications evaluated as separate endpoints or were they combined?

- Appreciate the appropriateness of statistical analyses employed.

To help the reader navigate this information we synthesize evidence of genetic influences by outcome studied: 1) warfarin dose, 2) anticoagulation maintenance, 3) risk of overanticoagulation, and 4) risk of hemorrhagic complications. We review the evidence from observational studies and the recent evidence emerging from prospective and randomized studies comparing pre-prescription genotyping with standard medical care.

Although past efforts focused on patients of mainly European descent in the U.S. and in Asia, recent investigations have included African American sub-groups facilitating race-stratified analyses. To put any racial differences in context the reader needs to be familiar with the nomenclature and differences in the reported frequencies of CYP2C9 and VKORCI polymorphisms. Structural polymorphism in the CYP2C9 and VKORC1 genes create variant alleles (Single nucleotide Polymorphisms, SNPs), which encode enzymes with different catalytic activity. The Human Cytochrome P450 (CYP) Allele Nomenclature committee recognizes 37 alleles for $C Y P 2 C 9$ (http://www.cypalleles.ki.se/cyp2c9.htm) with CYP2C9*1 designated as wild-type (normal metabolizer). In general possession of two copies of the variant allele is associated with a greater dose reduction compared to possession of one copies. Possession of $C Y P 2 C 9 * 2$ variant is associated with a smaller dose reduction than possession of the *3 variant (Table 1). ${ }^{23}$ Of the variant $C Y P 2 C 9$ alleles $C Y P 2 C 9 * 2$, and $C Y P 2 C 9 * 3$ are the most common variant alleles associated with reduced catalytic activity in patients of European, African, or Asian descent. ${ }^{24-29}$ Both CYP $2 C 9 * 2$ and $* 3$ are more prevalent among European Americans compared to African Americans ${ }^{24,30-32}$ CYP2C9*5 (0.9-1.8\%), CYP2C $9 * 6(0.1 \%)$ and $C Y P 2 C 9 * 11(1.5 \%)$ are putative poor metabolizer alleles found among African Americans. ${ }^{24,30,33,34}$ CYP2C9 variants are relatively rare in Asian populations, with a CYP2C9*3 frequency of 2-4\% and CYP2C $9 * 2$ generally not found. ${ }^{25-28}$

Although the influence of several VKORC1 polymorphisms (3730G/A (rs7294), 2255C/T (rs2359612), 1542G/C (rs8050894), 1173C/T (rs9934438) and -1639G/A (rs9923231)) on 
warfarin response has been investigated, $1173 C / T$ and $-1639 G / A$ have been the most widely studied. ${ }^{7}$ The $1173 C / T$ and $-1639 G / A$ polymorphisms (along with $2255 C / T$ 1542G/C, $-4931 T / C$ (rs7196161)) are in strong linkage disequilibrium (LD) in European Americans and are associated with lower mRNA levels. ${ }^{35}$ Polymorphisms in strong LD almost always appear together allowing the assessment of a single marker without loss of statistical power. There is limited knowledge with regard to the degree of LD of between other VKORC1 polymorphisms among African Americans and other racial / ethnic groups. ${ }^{24,32}$

The prevalence of variant VKORC1-1173 genotype (CT or TT) or variant VKORC1-1639 genotype ( $G A$ or $A A)$ is significantly higher among European Americans compared to African Americans, and higher yet in Asian populations. ${ }^{24,32,36}$ These differences appear to explain the majority of dose requirement differences observed by clinicians across these groups. The frequency of these polymorphisms may differ slightly across studies due to differences in ancestry, racial admixture and cohort size.

\section{OBSERVATIONAL STUDIES}

\section{Influence of CYP2C9 and VKORC1 on warfarin dose}

Recognition of the vast inter-individual variation in warfarin dose requirements, and the influence of factors such as age, gender, medications, vitamin $\mathrm{K}$ intake, liver function, has lead to development of several dosing algorithms to predict initial warfarin dose. ${ }^{37}$ Current practice involves the estimation of initial dose based on clinical characteristics followed by adjustment based on INR response with the goal of maintaining INR in the target range. Therefore a more accurate prediction of initial dose could improve anticoagulation control.

The association between $C Y P 2 C 9$ genotype and warfarin dosing requirements is robust, with a number of confirmatory studies in populations of European and Asian descent 13,17,22,25, $26,28,38-5051$ The average warfarin dose for patients with wild-type CYP2C9 genotype is approximately $6 \mathrm{mg} /$ day, those with two copies of the $* 2$ variant have an average daily dose of $4 \mathrm{mg} /$ day and those with two copies of the $* 3$ variant have an average daily dose of about $1.5 \mathrm{mg} /$ day. ${ }^{40}$ Among African Americans, CYP2C9 genotype has not demonstrated a consistent influence on warfarin dose. ${ }^{24,30,31,52}$ However the low prevalence of the variant CYP2C9 genotype, rather than lack of effect, is the more likely explanation. The influence of $C Y P 2 C 9 * 5$, *6 and *11 variants among African Americans is not well documented. ${ }^{24,30,52,53}$ In Asian populations, CYP2C9*3 has been shown to be associated with lower dose requirements. ${ }^{27}$

The more recent identification of $V K O R C 1$ as the warfarin drug $\operatorname{target}^{12}$ spurred efforts to understand its effect on warfarin dose. We therefore provide a synthesis of data from studies that have evaluated the influence of both CYP $2 C 9$ and VKORC1 on warfarin dose. First, however, it is important to recognize that the definition of 'dose requirement' can vary. In general, the goal has been to identify the warfarin dose at which a patient is maintained within therapeutic range. Thus, a common definition is the dose at which a patient achieves 3 consecutive INRs in range. However, the time period over which this occurs (i.e. 3 days vs. 9 months) can vary, introducing some variability. Thus time restrictions of, e.g., between 2 weeks and 3 months, may be included in the definition, as well as allowing small (e.g., $+/-10 \%$ ) dose variations.

As noted above, a single polymorphic site in $V K O R C 1,1173 \mathrm{C}>\mathrm{T}$, has been consistently associated with inter-individual variability in warfarin dose among patients of European, Asian and African descent. ${ }^{13,15,17,25-28,32,35,44-47,49-51,54-59}$ The average warfarin dose for patients with the $1173 \mathrm{CC}$ form is about $6 \mathrm{mg} /$ day, the CT form is about $5 \mathrm{mg} /$ day and the TT form of VKORCl is approximately $3 \mathrm{mg} / \mathrm{day} .{ }^{35} \mathrm{In}$ addition, differences in dose requirements 
among racial groups may be largely related to the prevalence of $V K O R C 1$ variants across populations $25,35,50$

Another approach to evaluating the relationship between genotype and dose is to build a statistical model that incorporates a variety of factors (i.e., clinical, demographic and genetic) to estimate the influence of each factor on dose requirements, and also control for potential confounding factors. Such analyses have demonstrated that polymorphisms in VKORC1 account for $25 \pm 8 \%$ of the variance in warfarin dose while CYP2C9 explains approximately $6-10 \% .25,35,50,60$

These statistical models, often referred to as 'pharmacogenetic dosing algorithms', can also be used to predict what the maintenance dose might be for a patient before beginning warfarin or early in therapy. ${ }^{27,46,61-64}$ These models differ slightly in the clinical and demographic factors that have been included (e.g., weight vs. height), and the way genetic variants are categorized (e.g. genotypes included as covariates with 2 levels; wild-type versus variant or as covariates with 3 levels; wild-type homozygote, variant heterozygote, variant homozygote). However, the general trends have been similar. One model, developed by Gage and colleagues, is publicly available at www.warfarindosing.org. In a recent review, McClain and colleagues ${ }^{65}$ utilized the algorithm described in Table 2 to predict to predict warfarin dose requirements for an individual based on genetic characteristics.

In summary, variants of both $C Y P 2 C 9$ and $V K O R C 1$ have a significant influence on warfarin dose requirements, and models have been developed to help predict maintenance doses.

Patients generally fall into three categories: 1) those with a 'high dose' VKORC1 genotype and no $C Y P 2 C 9$ variants requiring $6-7 \mathrm{mg} / \mathrm{d}, 2)$ those with a mix of variants requiring moderate doses of 2.5-6.0 mg/d, and 3) patients with 2 copies of a low dose genotype (of either gene) that require doses in the $1.5-2.5 \mathrm{mg} / \mathrm{d}$ range (Table 2 ).

At the other end of the dose spectrum, several rare VKORC1 missense mutations have been described in patients who are "resistant" and require higher warfarin doses (>70 mg/week). $12,59,66-70$ The frequency of these mutations and their clinical impact at a population level has not been extensively documented. However they may be clinically relevant in compliant patients requiring higher warfarin doses.

\section{Influence of CYP2C9 and VKORC1 on anticoagulation attainment and maintenance}

During initiation of warfarin therapy, the current standard of care recommends discontinuation of heparin in patients has two consecutive INRs in target range and monitoring patients at least weekly for the first month of therapy. Improved prediction of time required to attain target INR (enable discharge planning) and time required to attain stable maintenance dose (enable scheduling of outpatient visits) would enhance the clinical utility genotype-based therapy. ${ }^{37}$ The goal of anticoagulation services is to maintain INR in target range. Therefore the ability to identify patients (for example; with specific genotypic characteristics) who are prone to be over-anticoagulated or under-anticoagulated could improve the quality of anticoagulation control by allowing preemptive intervention (e.g. more frequent monitoring).

Several investigators have evaluated the influence of $C Y P 2 C 9$ and VKORC1 on time to target INR (calculated as the time from the initiation of therapy until first INR in-range is measured) and time to stable INR (or stable dose; is calculated as the time from the initiation of therapy until attainment of stable dose; typically the first dose that maintains INR in target range over three consecutive visits, with these INR measurements encompassing a period of at least 2 weeks) The influence of $C Y P 2 C 9$ and $V K O R C 1$ on time spent in target range can be assessed using two measures; proportion of INRs in range (calculated by dividing taking the number of 
INRs within target range by the total number of INRs during follow-up) and proportion of time spent in target range (estimated using the Rosendaal linear interpolation method). ${ }^{71,72}$

Although several studies have assessed the genetic influences on time to attain target INR ${ }^{40}$ and time to attain stable dose, $31,32,39,40,56,57,73-75$ only two have evaluated time spent in target INR range (Table 3). ${ }^{39,73}$ These observational studies demonstrate inconsistent influence of $C Y P 2 C 9$ and / or VKORC1 genotype on time to attain first INR in target range. ${ }^{40,51}$ Time to attain stable dose was reported to be longer among participants of European descent with

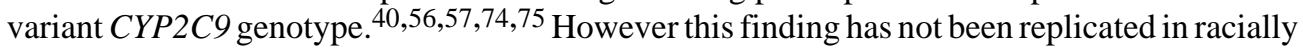
diverse cohorts. ${ }^{24,31,32}$ The three published observational studies that evaluated the influence of these genes on the time spent in target INR range found no association. ${ }^{24,39,73}$

\section{Influence of CYP2C9 and VKORC1 on risk of over-anticoagulation and hemorrhage}

The fear of major hemorrhagic complications is a major deterrent to the use of warfarin, in an otherwise qualifying patient. ${ }^{3,76}$ Recent reports estimate hemorrhagic complication rates of 5$7.9 \%$ for major (serious, life-threatening, or fatal) hemorrhage and $14-36 \%$ for minor (e.g. nose bleeds, microscopic hematuria) hemorrhage. ${ }^{77,78}$ Patient characteristics such as age $\geq$ 75years, history of gastrointestinal bleeding, history of stroke, recent myocardial infarction, renal insufficiency, hypertension, concomitant drugs, higher intensity of treatment, and longer duration of anticoagulation therapy have been associated with a higher risk of hemorrhagic complications. ${ }^{77,79}$

Hemorrhagic events are more likely to occur during the first 3 months of treatment, perhaps as a consequence of over-anticoagulation as dose is being individualized. ${ }^{40,77,79}$ An elevated INR (over-anticoagulation) is a strong and independent risk factor for hemorrhagic complications. ${ }^{80,81}$ This recognition has promoted its utilization as a surrogate marker for hemorrhagic risk. However over-anticoagulation does not always precede a hemorrhagic complication. Therefore we caution the reader to understand what is being estimated, risk of over-anticoagulation or risk of hemorrhage; and not to equate over-anticoagulation to a hemorrhagic event.

Although several studies have reported an increased risk of hemorrhage among patients with a variant $C Y P 2 C 9$ genotype, most have defined the event as 'over-anticoagulation' rather than a hemorrhagic event (Table 4). ${ }^{32,39,51,56,57,74,75}$ Although these studies indicate a higher risk of over-anticoagulation among patients who possess the variant CYP2C9 and / or VKORC1 genotype drawing comparisons between study findings is difficult for several reasons. First, the definition of over-anticoagulation varies from INR $>3^{32}$ to INR $>8 .{ }^{39}$ Second, differing pharmacokinetics of coumarins studied make comparisons of genetic contributions tenuous. Third, study duration and follow-up differed as did time points at which gene-response associations were evaluated. Fourth, the differences in ethnic/ racial groups and the factors such as exclusion of patients on concomitant medications that interact with coumarins limit the generalizability of findings. ${ }^{56,57}$ Fifth, the influence of variation in environmental factors (e.g. changes in vitamin $\mathrm{K}$ intake, medications) known to influence warfarin response was not consistently accounted for in assessing gene-over-anticoagulation association. Sixth, recent data in racially diverse cohorts confirms the increased risk among patients of European descent but suggests a protective effect in African Americans. ${ }^{24,31,32}$

Four studies have reported the risk of hemorrhage associated with $C Y P 2 C 9,36,38,40,82$ with three assessing bleeding risk by genotype (Table 5). ${ }^{36,38,40}$ Aithal et al reported the higher hemorrhagic risk among patients requiring low-dose warfarin $(<1.5 \mathrm{mg} / \mathrm{day})$ in a case-control study. ${ }^{82}$ 
The association between $C Y P 2 C 9$ and hemorrhagic risk was deduced (rather than assessed directly) from the higher prevalence of the variant $C Y P 2 C 9$ genotype among patients requiring low dose. Margaglione et al reported a 2.6-fold higher risk of hemorrhage among patients with CYP2C9 variants. ${ }^{38}$ However the rarity of serious/life-threatening bleeding $(\mathrm{n}=10)$ necessitated evaluation of major and minor hemorrhage as a composite outcome. Higashi et al demonstrated the risk of major hemorrhage associated with variant $C Y P 2 C 9$ genotype was higher during initiation of therapy [RR 3.9, 95\% CI: 1.3, 12.1] and during the entire follow-up period [RR 2.4, 95\% CI: $1.2,4.9]{ }^{40}$

A recent study assessing the effect of $C Y P 2 C 9$ and $V K O R C 1$ on the risk of hemorrhage provides evidence of an association of variant $C Y P 2 C 9$ genotype and risk of major hemorrhage [RR 3.0, 95\% CI: 1.2, 7.5] in both African and European American patients after accounting for the effects of VKORC1 1173C/T, and clinical covariates. ${ }^{36}$ Interestingly, variant VKORC1-1173C/ $T$ genotype did not confer a significant increase in risk for major hemorrhage [RR 1.7, 95\% CI: 0.7, 4.4]. There are several potential explanations for this, including 1) the fact that 5-10\% of patients had a VKORC1 low dose genotype, versus $30 \%$ of patients had a CYP2C9 low dose genotype; 2) the influence of CYP2C9 on warfarin metabolism half life; and 3) an association between $C Y P 2 C 9$ and bleeding risk unrelated to warfarin anticoagulation therapy/INR. ${ }^{84}$

Perhaps more importantly, this study found the risk associated with the variant $C Y P 2 C 9$ genotype is independent of the INR at the time of the event and persists even after stabilization of anticoagulation therapy. This implies that patients possessing $C Y P 2 C 9$ variant may be susceptible to hemorrhage at similar intensity of anticoagulation. The persistence of risk after stabilization suggests that patients possessing CYP2C 9 variants may need more conservative dose adjustments or INR target range than those with wild-type genotype, but additional research in this area is needed.

\section{PROSPECTIVE AND RANDOMIZED STUDIES}

\section{Non-comparative studies}

The evidence of genetic influence on warfarin response and the availability of rapid-throughput genotyping technology fueled several prospective efforts aiming to determine utility of preprescription genotyping. Pilot studies by Hillman et al and Voora et al demonstrated the feasibility of pre-prescriptive $C Y P 2 C 9$ genotyping and improved predictability of warfarin dose. ${ }^{64,85}$ Pharmacogenetics-based dosing did not alter the proportion of time spent in target range or the risk of over-anticoagulation associated variant CYP2C9 genotype. However it must be noted that both studies were not adequately powered to detect such differences.

Two recent studies extended this effort include pre-prescription CYP2C9 and VKORC1 genotyping. Millican et al evaluated therapeutic dose (dose that gave an INR in the target therapeutic range after 6 or 7 consecutive days) prediction in 92 subjects (86\% European American, 52\% men). They implemented a dose revision protocol utilizing prior doses administered and INR response in addition to CYP2C9 (*2 and *3) and VKORC1-1639G/A, clinical and socio-demographic variables. The final algorithm explained $79 \%$ of the variability in warfarin dose. The final models' higher prediction ability stems mainly from using prior dose and INR response to predict therapeutic dose. However, the statistical significance of CYP2C9 and VKORClgenotype indicate a potential for further dose refinement (e.g. after an initial $5 \mathrm{mg}$ dose) by inclusion of genotype information. ${ }^{63} \mathrm{Wen}$ et al evaluated stable dose (dose that produced $\geq 2$ consecutive INRs in target range $\geq 7$ days apart) prediction and time to stabilization in 108 Han-Chinese subjects $(60 \%$ men). The inclusion CYP2C9 $* 3$ and VKORC1-1639G/A, BSA and age explained $48 \%$ of variability in warfarin dose. However the lack of a control group did not allow assessment of whether pharmacogenetics-based dosing 
can shorten the time of achieving a stable, therapeutic warfarin INR and reduce the number of adverse events compared to standard of care. ${ }^{86}$

\section{Comparative controlled studies}

The impact of genotype-guided dosing on clinical outcomes has been evaluated in two randomized controlled trails to date (Table 6) comparing standard medical care with genotypebased dose initiation. Caraco et al reported shorter time to first therapeutic INR and first stable INR among patients receiving CYP2C9 genotype-guided therapy ${ }^{87}$ However, this finding is driven primarily by the higher daily dose assigned to wild-type patients in the pharmacogeneticguided group. Furthermore, different durations of follow-up were reported for the two study groups during the maintenance phase, making comparisons challenging.

A more recent study by Anderson et al in 200 patients, genotype-guided dosing provided superior dose prediction. The variance in warfarin dose explained by CYP $2 C 9$ and VKORC1 genotype (32\%) was two-fold higher than that explained by clinical factors (15\%). Most of the benefits were derived by appropriately dosing the patients possessing no variant alleles and those possessing multiple variant alleles. However the study failed to demonstrate an increase in the percentage of INRs within the therapeutic range by institution of genotype-guided therapy. ${ }^{88}$ Differences in indication for therapy between the groups (due to chance) may have introduced some confounding to the study results. The overall effect of genotyping may have been mitigated because the $80 \%$ of patients were initiated in the hospital and followed intensively by anticoagulation specialists.

Despite the negative primary end point, exploratory analyses by Anderson et al identified two genotypic subgroups that benefited from genotype-guided therapy: wild-type patients (whose dose requirements are greater than average) and carriers of multiple variant alleles (whose dose requirements are lower than average). In these patient subgroups, pharmacogenetic guidance yielded a $10 \%$ increase in within-range INRs $(\mathrm{p}=0.03){ }^{88}$

The discrepancies in findings with regard to time spent in range and over-anticoagulation (INR $>4$ ) between observational and interventional studies can perhaps be explained by the frequency of INR monitoring and duration of follow-up. Observations studies evaluate geneeffects over a more prolonged time span, under conditions that reflect routine medical care. In both randomized studies (Table 6), the brief follow-up and the INR assessment schedule, far more aggressive than routine clinical practice, could have contributed to better than expected outcomes in the standard-medical-care arm. As reported by Anderson et al ${ }^{88}$ time spent in therapeutic INR (68.6\%) among participants assigned to standard-medical care arm was greater than that for usual/ routine medical care (37\%-60\%) and for and for anticoagulation clinic care (40\%-60\%). ${ }^{89-91}$ An INR assessment schedule more reflective of outpatient anticoagulation management may have yielded different results.

\section{Promise faced with challenges}

Warfarin pharmacogenomics has become an important case-study for genomic technologies. It holds promise with the potential for improving the safety and effectiveness of this life-saving, albeit historically challenging therapy. However the excitement surrounding this potential is faced with potential pitfalls, which perhaps will be alleviated by ongoing and future studies.

Although genotype-guided dosing offers superior dose prediction compared to current dosing algorithms, it is by no means guaranteed to improve patient outcomes. We must appreciate that genotype-based algorithms have been shown to explain 40-60\% of variance in warfarin dose and failure to recognize the impact of other unknown variables (that account for the remaining 
40-60\%) could result in over or under-dosing. Moreover individual dose requirements may change over time with changes in diet, concomitant medications, and concurrent illness.

The perception of perfect prediction with genotype-based algorithms may create a false sense of security resulting less stringent INR monitoring. While one can argue that by more accurate dose prediction one can improve anticoagulation maintenance, this hypothesis is not supported by current evidence.

Although the variant $C Y P 2 C 9$ genotype is associated with an increased risk of hemorrhage as highlighted in many news features, ${ }^{92,93}$ all the evidence is from observational studies.

Therefore we hesitate to recommend the employment of genotype information in determining individual hemorrhagic risk. Our trepidation lies in the potential (mis)use of this information to make treatment choices. While variant $C Y P 2 C 9$ genotype may increase the risk of hemorrhage, without understanding the risk of recurrent thromboembolism (in patients with variant $C Y P 2 C 9$ ) withholding therapy may have even more deleterious consequences. We have inadequate evidence to make a balanced "treat or withhold treatment" decision. Risk prediction will require both pieces of information if we are to honour the Hippocratic Oath "First, do no harm........"

Recently, the American Enterprise Institute -Brooking Joint Center for Regulatory Studies (with input from the FDA) released optimistic projections on the cost-effectiveness of warfarin pharmacogenomics. However, the validity of these findings has been called to question. ${ }^{94}$ The availability and the declining cost of genomic technologies may make genotyping feasible and affordable, but evidence of effectiveness must precede determination of cost-effectiveness. If found effective, genotype-guided therapy could be a success with improvement in outcomes offsetting the increase in healthcare cost due to testing.

While many studies have sought to evaluate the association between genetic variants and overanticoagulation and hemorrhage, only Schelleman et al attempted to understand the influence of genetic variants on under-anticoagulation (INR $<2$ ). ${ }^{32}$ Moreover no study has evaluated the association between variants and thromboembolic events among patients on warfarin. As evidenced by many reports, under-anticoagulation is a more frequent problem than overanticoagulation. ${ }^{89,91}$ Understanding the association (if any) with thromboembolism will be crucial in evaluating the effectiveness of genotype-based therapy. Furthermore, these associations can have profound influence on the assumptions and results of economic analyses.

\section{Future directions}

Future efforts must involve prospective trails in racially diverse cohorts (to improve generalizability) with long-tem follow-up (to assess incident hemorrhagic and thromboembolic complications) and detailed documentation of environmental influences. The resulting longitudinal data will facilitate the evaluation of differential genetic / environmental effects over time and assessment gene-environment interactions. Such studies will need to assess whether genotype-guided therapy improves patient outcomes, identify which subgroups of patients may benefit, and clarify the risks and costs associated with the use of these tests.

Recognition of the potential promise of genotype-guided therapy has spurred several national and international efforts. The National Heart Lung and Blood Institute recently announced its sponsorship of a randomized clinical trial to evaluate the effectiveness of genotype-guided therapy in improving anticoagulation outcomes. The study will randomize about 2000 patients at about 15 clinical sites to three approaches to warfarin therapy initiation: (1) an algorithm that incorporates clinical information and the person's genotype for $C Y P 2 C 9$ and $V K O R C 1$, (2) an algorithm that incorporates only clinical information, and (3) a standard, guideline-based 
strategy. All patients in this double-blind study will have a clinical need for long-term anticoagulation, be new to warfarin therapy, and undergo monitoring for one year.

As such research efforts are initiated and pre-prescription genotyping is implemented, it will be critical to select a common and limited set of genetic polymorphisms and clinical factors that can improve prediction of warfarin dose requirements for a racially diverse population. Recognition of the potential of pharmacogenetics in warfarin therapy has fostered an international effort; the International Warfarin Pharmacogenomics Consortium (IWPC). This collaborative effort aims to develop a universally applicable algorithm for warfarin dosing based on $C Y P 2 C 9$ and $V K O R C 1$ and clinical variables that influence warfarin response across ethnic/racial groups. The IWPC has pooled data on 5700 patients from 21 investigators from four continents around the world. This large dataset will allow assessment of genetic influences across racial and ethnic groups, provide a robust estimate of gene effects, enable evaluation of interactions and allow the determination of a limited set of genetic and clinical variables that can be easily implemented in research and practice.

\section{Conclusion}

The influence of $C Y P 2 C 9$ and VKORC1 genotype on warfarin dose has been consistently demonstrated in a large number of patients with various indications, by multiple investigators in diverse racial/ ethnic groups in observational studies. Recent randomized clinical trails validate the ability of genotype-guided dosing to estimate warfarin maintenance dose. However, to date we do not have supporting evidence to suggest genotype-guided therapy will improve anticoagulation control and prevent or reduce the risk of hemorrhagic or thromboembolic complications. However, it would be reasonable to use CYP2C9 and $V K O R C 1$ genotype as part of diagnostic efforts to understand unusual response (e.g. extremely elevated INR during initiation) to standard medical care.

\section{Acknowledgments}

Supported in part by a grant from the National Institute of Neurological Disorders and Stroke (Grant Number: K23NS45598-01) and CDC's Office of Genomics and Disease Prevention Seed Funding for Public Health Genomics Research

\section{References}

1. Ansell J, Hirsh J, Poller L, Bussey H, Jacobson A, Hylek E. The pharmacology and management of the vitamin K antagonists: the Seventh ACCP Conference on Antithrombotic and Thrombolytic Therapy. Chest 2004;126:204S-233S. [PubMed: 15383473]

2. Hirsh J, Guyatt G, Albers GW, Schunemann HJ. The Seventh ACCP Conference on Antithrombotic and Thrombolytic Therapy: evidence-based guidelines. Chest 2004;126:172S-173S. [PubMed: 15383469]

3. Wittkowsky AK. Effective anticoagulation therapy: defining the gap between clinical studies and clinical practice. Am J Manag Care 2004;10:S297-306. [PubMed: 15605700]discussion S312-297

4. Stafford RS, Radley DC. The underutilization of cardiac medications of proven benefit, 1990 to 2002. J Am Coll Cardiol 2003;41:56-61. [PubMed: 12570945]

5. Guo GB, Chang HW, Chen MC, Yang CH. Underutilization of anticoagulation therapy in chronic atrial fibrillation. Jpn Heart J 2001;42:55-65. [PubMed: 11324807]

6. Flaker GC, McGowan DJ, Boechler M, Fortune G, Gage B. Underutilization of antithrombotic therapy in elderly rural patients with atrial fibrillation. Am Heart J 1999;137:307-312. [PubMed: 9924165]

7. Wadelius M, Pirmohamed M. Pharmacogenetics of warfarin: current status and future challenges. Pharmacogenomics Journal. 2006

8. Kaminsky LS, Zhang ZY. Human P450 metabolism of warfarin. Pharmacology \& Therapeutics 1997;73:67-74. [PubMed: 9014207] 
9. Rettie AE, Korzekwa KR, Kunze KL, et al. Hydroxylation of warfarin by human cDNA-expressed cytochrome P-450: a role for P-4502C9 in the etiology of (S)-warfarin-drug interactions. Chemical Research in Toxicology 1992;5:54-59. [PubMed: 1581537]

10. Miners JO, Birkett DJ. Cytochrome P4502C9: an enzyme of major importance in human drug metabolism. Br J Clin Pharmacol 1998;45:525-538. [PubMed: 9663807]

11. Wallin R, Hutson SM. Warfarin and the vitamin K-dependent gamma-carboxylation system. Trends Mol Med 2004;10:299-302. [PubMed: 15242675]

12. Li T, Chang CY, Jin DY, Lin PJ, Khvorova A, Stafford DW. Identification of the gene for vitamin K epoxide reductase. Nature 2004;427:541-544. [PubMed: 14765195]

13. Herman D, Peternel P, Stegnar M, Breskvar K, Dolzan V. The influence of sequence variations in factor VII, gamma-glutamyl carboxylase and vitamin K epoxide reductase complex genes on warfarin dose requirement. Thrombosis \& Haemostasis 2006;95:782-787. [PubMed: 16676068]

14. Vecsler M, Loebstein R, Almog S, et al. Combined genetic profiles of components and regulators of the vitamin K-dependent gamma-carboxylation system affect individual sensitivity to warfarin. Thrombosis \& Haemostasis 2006;95:205-211. [PubMed: 16493479]

15. Wadelius M, Chen LY, Downes K, et al. Common VKORC1 and GGCX polymorphisms associated with warfarin dose. Pharmacogenomics J 2005;5:262-270. [PubMed: 15883587]

16. Kimura R, Kokubo Y, Miyashita K, et al. Polymorphisms in vitamin K-dependent gammacarboxylation-related genes influence interindividual variability in plasma protein $\mathrm{C}$ and protein $\mathrm{S}$ activities in the general population. Int J Hematol 2006;84:387-397. [PubMed: 17189218]

17. Aquilante CL, Langaee TY, Lopez LM, et al. Influence of coagulation factor, vitamin K epoxide reductase complex subunit 1 , and cytochrome P450 2C9 gene polymorphisms on warfarin dose requirements. Clin Pharmacol Ther 2006;79:291-302. [PubMed: 16580898]

18. Sconce EA, Daly AK, Khan TI, Wynne HA, Kamali F. APOE genotype makes a small contribution to warfarin dose requirements. Pharmacogenet Genomics 2006;16:609-611. [PubMed: 16847429]

19. Kohnke H, Scordo MG, Pengo V, Padrini R, Wadelius M. Apolipoprotein E (APOE) and warfarin dosing in an Italian population. Eur J Clin Pharmacol 2005;61:781-783. [PubMed: 16133550]

20. Kimmel SE, Christie J, Kealey C, et al. Apolipoprotein E genotype and warfarin dosing among Caucasians and African Americans. Pharmacogenomics J 2008;8:53-60. [PubMed: 17325732]

21. Wadelius M, Sorlin K, Wallerman O, et al. Warfarin sensitivity related to CYP2C9, CYP3A5, ABCB1 (MDR1) and other factors. Pharmacogenomics Journal 2004;4:40-48. [PubMed: 14676821]

22. Loebstein R, Vecsler M, Kurnik D, et al. Common genetic variants of microsomal epoxide hydrolase affect warfarin dose requirements beyond the effect of cytochrome P450 2C9. Clinical Pharmacology \& Therapeutics 2005;77:365-372. [PubMed: 15900282]

23. Lee CR, Goldstein JA, Pieper JA. Cytochrome P450 2C9 polymorphisms: a comprehensive review of the in-vitro and human data. Pharmacogenetics 2002;12:251-263. [PubMed: 11927841]

24. Limdi NA, Arnett DK, Goldstein JA, et al. Influence of $C Y P 2 C 9$ and VKORC1 polymorphisms on warfarin dose, anticoagulation attainment and maintenance among European American and African Americans. Pharmacogenomics. 2008(in press)

25. Veenstra DL, You JH, Rieder MJ, et al. Association of Vitamin K epoxide reductase complex 1 (VKORC1) variants with warfarin dose in a Hong Kong Chinese patient population. Pharmacogenetics \& Genomics 2005;15:687-691. [PubMed: 16141794]

26. Yuan HY, Chen JJ, Lee MT, et al. A novel functional VKORC1 promoter polymorphism is associated with inter-individual and inter-ethnic differences in warfarin sensitivity. Human Molecular Genetics 2005;14:1745-1751. [PubMed: 15888487]

27. Tham LS, Goh BC, Nafziger A, et al. A warfarin-dosing model in Asians that uses single-nucleotide polymorphisms in vitamin K epoxide reductase complex and cytochrome P450 2C9. Clin Pharmacol Ther 2006;80:346-355. [PubMed: 17015052]

28. Takahashi H, Wilkinson GR, Nutescu EA, et al. Different contributions of polymorphisms in VKORC1 and CYP2C9 to intra- and inter-population differences in maintenance dose of warfarin in Japanese, Caucasians and African-Americans. Pharmacogenet Genomics 2006;16:101-110. [PubMed: 16424822] 
29. Gage BF, Milligan PE. Pharmacology and pharmacogenetics of warfarin and other coumarins when used with supplements. Thrombosis Research 2005;117:55-59. [PubMed: 16043212]discussion 65-57

30. Limdi NA, Goldstein JA, Blaisdell JA, Beasley TM, Rivers CA, Acton RT. Influence of CYP2C9 Genotype on warfarin dose among African American and European Americans. Personalized Medicine 2007;4:157-169.

31. Kealey C, Chen Z, Christie J, et al. Warfarin and cytochrome P450 2C9 genotype: possible ethnic variation in warfarin sensitivity. Pharmacogenomics 2007;8:217-225. [PubMed: 17324110]

32. Schelleman H, Chen Z, Kealey C, et al. Warfarin Response and Vitamin K Epoxide Reductase Complex 1 in African Americans and Caucasians. Clin Pharmacol Ther. 2007

33. Blaisdell J, Jorge-Nebert LF, Coulter S, et al. Discovery of new potentially defective alleles of human CYP2C9. Pharmacogenetics 2004;14:527-537. [PubMed: 15284535]

34. Xie HG, Prasad HC, Kim RB, Stein CM. CYP2C9 allelic variants: ethnic distribution and functional significance. Adv Drug Deliv Rev 2002;54:1257-1270. [PubMed: 12406644]

35. Rieder MJ, Reiner AP, Gage BF, et al. Effect of VKORC1 haplotypes on transcriptional regulation and warfarin dose. New England Journal of Medicine 2005;352:2285-2293. [PubMed: 15930419]

36. Limdi N, McGwin G, Goldstein J, et al. Influence of CYP2C9 and VKORC1 1173C/T Genotype on the Risk of Hemorrhagic Complications in African-American and European-American Patients on Warfarin. Mol Ther 2008;83:312-321.

37. Ansell, JEOL.; Wittkowsky, AK. Managing Oral Anticoagulation Therapy: Clinical and Operational Guidelines. Vol. 2nd edition. St. Louis, MO: Lippincott Williams \& Wilkins; 2005.

38. Margaglione M, Colaizzo D, D'Andrea G, et al. Genetic modulation of oral anticoagulation with warfarin. Thrombosis \& Haemostasis 2000;84:775-778. [PubMed: 11127854]

39. Taube J, Halsall D, Baglin T. Influence of cytochrome P-450 CYP2C9 polymorphisms on warfarin sensitivity and risk of over-anticoagulation in patients on long-term treatment. Blood 2000;96:18161819. [PubMed: 10961881]

40. Higashi MK, Veenstra DL, Kondo LM, et al. Association between CYP2C9 genetic variants and anticoagulation-related outcomes during warfarin therapy. JAMA 2002;287:1690-1698. [PubMed: 11926893]

41. Loebstein R, Yonath H, Peleg D, et al. Interindividual variability in sensitivity to warfarin--Nature or nurture? Clinical Pharmacology \& Therapeutics 2001;70:159-164. [PubMed: 11503010]

42. Tabrizi AR, Zehnbauer BA, Borecki IB, McGrath SD, Buchman TG, Freeman BD. The frequency and effects of cytochrome $\mathrm{P} 450$ (CYP) $2 \mathrm{C} 9$ polymorphisms in patients receiving warfarin. Journal of the American College of Surgeons 2002;194:267-273. [PubMed: 11893129]

43. Adcock DM, Koftan C, Crisan D, Kiechle FL. Effect of polymorphisms in the cytochrome P450 CYP2C9 gene on warfarin anticoagulation. Archives of Pathology \& Laboratory Medicine 2004;128:1360-1363. [PubMed: 15578879]

44. Bodin L, Verstuyft C, Tregouet DA, et al. Cytochrome P450 2C9 (CYP2C9) and vitamin K epoxide reductase (VKORC1) genotypes as determinants of acenocoumarol sensitivity. Blood 2005;106:135140. [PubMed: 15790782]

45. D'Andrea G, D'Ambrosio RL, Di Perna P, et al. A polymorphism in the VKORC1 gene is associated with an interindividual variability in the dose-anticoagulant effect of warfarin. Blood 2005;105:645649. [PubMed: 15358623]

46. Sconce EA, Khan TI, Wynne HA, et al. The impact of CYP2C9 and VKORC1 genetic polymorphism and patient characteristics upon warfarin dose requirements: proposal for a new dosing regimen. Blood 2005;106:2329-2333. [PubMed: 15947090]

47. Geisen C, Watzka M, Sittinger K, et al. VKORC1 haplotypes and their impact on the inter-individual and inter-ethnical variability of oral anticoagulation. Thromb Haemost 2005;94:773-779. [PubMed: 16270629]

48. Montes R, Ruiz de Gaona E, Martinez-Gonzalez MA, Alberca I, Hermida J. The c.-1639G > A polymorphism of the VKORC1 gene is a major determinant of the response to acenocoumarol in anticoagulated patients. British Journal of Haematology 2006;133:183-187. [PubMed: 16611310] 
49. Mushiroda T, Ohnishi Y, Saito S, et al. Association of VKORC1 and CYP2C9 polymorphisms with warfarin dose requirements in Japanese patients. Journal of Human Genetics 2006;51:249-253. [PubMed: 16432637]

50. Obayashi K, Nakamura K, Kawana J, et al. VKORC1 gene variations are the major contributors of variation in warfarin dose in Japanese patients. Clin Pharmacol Ther 2006;80:169-178. [PubMed: 16890578]

51. Schwarz UI, Ritchie MD, Bradford Y, et al. Genetic determinants of response to warfarin during initial anticoagulation. N Engl J Med 2008;358:999-1008. [PubMed: 18322281]

52. Momary KM, Shapiro NL, Viana MA, Nutescu EA, Helgason CM, Cavallari LH. Factors influencing warfarin dose requirements in African-Americans. Pharmacogenomics 2007;8:1535-1544. [PubMed: 18034618]

53. Dickmann LJ, Rettie AE, Kneller MB, et al. Identification and functional characterization of a new CYP2C9 variant (CYP2C9*5) expressed among African Americans. Molecular Pharmacology 2001;60:382-387. [PubMed: 11455026]

54. Borgiani P, Ciccacci C, Forte V, Romano S, Federici G, Novelli G. Allelic variants in the CYP2C9 and VKORC1 loci and interindividual variability in the anticoagulant dose effect of warfarin in Italians. Pharmacogenomics 2007;8:1545-1550. [PubMed: 18034619]

55. Kosaki K, Yamaghishi C, Sato R, et al. 1173C $>$ T polymorphism in VKORC1 modulates the required warfarin dose. Pediatr Cardiol 2006;27:685-688. [PubMed: 17031720]

56. Schalekamp T, Brasse BP, Roijers JF, et al. VKORC1 and CYP2C9 genotypes and acenocoumarol anticoagulation status: interaction between both genotypes affects overanticoagulation. Clinical Pharmacology \& Therapeutics 2006;80:13-22. [PubMed: 16815313]

57. Schalekamp T, Brasse BP, Roijers JF, et al. VKORC1 and CYP2C9 genotypes and phenprocoumon anticoagulation status: interaction between both genotypes affects dose requirement. Clin Pharmacol Ther 2007;81:185-193. [PubMed: 17192772]

58. Osman A, Enstrom C, Arbring K, Soderkvist P, Lindahl TL. Main haplotypes and mutational analysis of vitamin K epoxide reductase (VKORC1) in a Swedish population: a retrospective analysis of case records. J Thromb Haemost 2006;4:1723-1729. [PubMed: 16879214]

59. Harrington DJ, Underwood S, Morse C, Shearer MJ, Tuddenham EG, Mumford AD. Pharmacodynamic resistance to warfarin associated with a Val66Met substitution in vitamin $\mathrm{K}$ epoxide reductase complex subunit 1. Thromb Haemost 2005;93:23-26. [PubMed: 15630486]

60. Schwarz UI, Stein CM. Genetic determinants of dose and clinical outcomes in patients receiving oral anticoagulants. Clin Pharmacol Ther 2006;80:7-12. [PubMed: 16815312]

61. Hillman MA, Wilke RA, Caldwell MD, Berg RL, Glurich I, Burmester JK. Relative impact of covariates in prescribing warfarin according to CYP2C9 genotype. Pharmacogenetics 2004; 14:539547. [PubMed: 15284536]

62. Kamali F, Khan TI, King BP, et al. Contribution of age, body size, and CYP2C9 genotype to anticoagulant response to warfarin. Clinical Pharmacology \& Therapeutics 2004;75:204-212. [PubMed: 15001972]

63. Millican EA, Lenzini PA, Milligan PE, et al. Genetic-based dosing in orthopedic patients beginning warfarin therapy. Blood 2007;110:1511-1515. [PubMed: 17387222]

64. Voora D, Eby C, Linder MW, et al. Prospective dosing of warfarin based on cytochrome P-450 2C9 genotype. Thrombosis \& Haemostasis 2005;93:700-705. [PubMed: 15841315]

65. McClain MR, Palomaki GE, Piper M, Haddow JE. A Rapid ACCE1 Review of CYP2C9 and VKORC1 Allele Testing to Inform Warfarin Dosing in Adults at Elevated Risk for Thrombotic Events to Avoid Serious Bleeding. American College of Medical Genetics. 2007

66. Bodin L, Horellou MH, Flaujac C, Loriot MA, Samama MM. A vitamin K epoxide reductase complex subunit-1 (VKORC1) mutation in a patient with vitamin K antagonist resistance. J Thromb Haemost 2005;3:1533-1535. [PubMed: 15978113]

67. D'Ambrosio RL, D'Andrea G, Cafolla A, Faillace F, Margaglione M. A new vitamin K epoxide reductase complex subunit-1 (VKORC1) mutation in a patient with decreased stability of CYP2C9 enzyme. J Thromb Haemost 2007;5:191-193. [PubMed: 17059426]

68. Loebstein R, Dvoskin I, Halkin H, et al. A coding VKORC1 Asp36Tyr polymorphism predisposes to warfarin resistance. Blood 2007;109:2477-2480. [PubMed: 17110455] 
69. Rost S, Fregin A, Ivaskevicius V, et al. Mutations in VKORC1 cause warfarin resistance and multiple coagulation factor deficiency type 2. Nature 2004;427:537-541. [PubMed: 14765194]

70. Scott SA, Edelmann L, Kornreich R, Desnick RJ. Warfarin pharmacogenetics: CYP2C9 and VKORC1 genotypes predict different sensitivity and resistance frequencies in the Ashkenazi and Sephardi Jewish populations. Am J Hum Genet 2008;82:495-500. [PubMed: 18252229]

71. Rosendaal FR, Cannegieter SC, van der Meer FJ, Briet E. A method to determine the optimal intensity of oral anticoagulant therapy. Thromb Haemost 1993;69:236-239. [PubMed: 8470047]

72. Schmitt L, Speckman J, Ansell J. Quality assessment of anticoagulation dose management: comparative evaluation of measures of time-in-therapeutic range. J Thromb Thrombolysis 2003;15:213-216. [PubMed: 14739631]

73. Lindh JD, Lundgren S, Holm L, Alfredsson L, Rane A. Several-fold increase in risk of overanticoagulation by CYP2C9 mutations. Clinical Pharmacology \& Therapeutics 2005;78:540 550. [PubMed: 16321620]

74. Schalekamp T, Oosterhof M, van Meegen E, et al. Effects of cytochrome P450 2C9 polymorphisms on phenprocoumon anticoagulation status. Clinical Pharmacology \& Therapeutics 2004;76:409-417. [PubMed: 15536456]

75. Schalekamp T, van Geest-Daalderop JH, de Vries-Goldschmeding H, Conemans J, Bernsen MjM, de Boer A. Acenocoumarol stabilization is delayed in CYP2C93 carriers. Clinical Pharmacology \& Therapeutics 2004;75:394-402. [PubMed: 15116052]

76. Ingelgard A, Hollowell J, Reddy P, Gold K, Tran K, Fitzmaurice D. What are the barriers to warfarin use in atrial fibrillation? Development of a questionnaire. J Thromb Thrombolysis 2006;21:257-265. [PubMed: 16683218]

77. Hylek EM. Complications of oral anticoagulant therapy: bleeding and nonbleeding, rates and risk factors. Seminars in Vascular Medicine 2003;3:271-278. [PubMed: 15199460]

78. Hylek EM, Evans-Molina C, Shea C, Henault LE, Regan S. Major hemorrhage and tolerability of warfarin in the first year of therapy among elderly patients with atrial fibrillation. Circulation 2007;115:2689-2696. [PubMed: 17515465]

79. Levine MN, Raskob G, Beyth RJ, Kearon C, Schulman S. Hemorrhagic complications of anticoagulant treatment: the Seventh ACCP Conference on Antithrombotic and Thrombolytic Therapy. Chest 2004;126:287S-310S. [PubMed: 15383476]

80. Hylek EM, Go AS, Chang Y, et al. Effect of intensity of oral anticoagulation on stroke severity and mortality in atrial fibrillation. N Engl J Med 2003;349:1019-1026. [PubMed: 12968085]

81. Hylek EM, Skates SJ, Sheehan MA, Singer DE. An analysis of the lowest effective intensity of prophylactic anticoagulation for patients with nonrheumatic atrial fibrillation. N Engl J Med 1996;335:540-546. [PubMed: 8678931]

82. Aithal GP, Day CP, Kesteven PJ, Daly AK. Association of polymorphisms in the cytochrome P450 CYP2C9 with warfarin dose requirement and risk of bleeding complications. Lancet 1999;353:717719. [PubMed: 10073515]

83. Fihn SD, McDonell M, Martin D, et al. Warfarin Optimized Outpatient Follow-up Study Group. Risk factors for complications of chronic anticoagulation. A multicenter study. Annals of Internal Medicine 1993;118:511-520. [PubMed: 8280198]

84. Pilotto A, Seripa D, Franceschi M, et al. Genetic susceptibility to nonsteroidal anti-inflammatory drug-related gastroduodenal bleeding: role of cytochrome P450 2C9 polymorphisms. Gastroenterology 2007;133:465-471. [PubMed: 17681167]

85. Hillman MA, Wilke RA, Yale SH, et al. A prospective, randomized pilot trial of model-based warfarin dose initiation using CYP2C9 genotype and clinical data. Clinical Medicine \& Research 2005;3:137145. [PubMed: 16160068]

86. Wen MS, Lee M, Chen JJ, et al. Prospective Study of Warfarin Dosage Requirements Based on CYP2C9 and VKORC1 Genotypes. Mol Ther. 2008

87. Caraco Y, Blotnick S, Muszkat M. CYP2C9 Genotype-guided Warfarin Prescribing Enhances the Efficacy and Safety of Anticoagulation: A Prospective Randomized Controlled Study. Clin Pharmacol Ther. 2007 
88. Anderson JL, Horne BD, Stevens SM, et al. Randomized trial of genotype-guided versus standard warfarin dosing in patients initiating oral anticoagulation. Circulation 2007;116:2563-2570. [PubMed: 17989110]

89. Ansell J, Hollowell J, Pengo V, Martinez-Brotons F, Caro J, Drouet L. Descriptive analysis of the process and quality of oral anticoagulation management in real-life practice in patients with chronic non-valvular atrial fibrillation: the international study of anticoagulation management (ISAM). $\mathrm{J}$ Thromb Thrombolysis 2007;23:83-91. [PubMed: 17221328]

90. Chamberlain MA, Sageser NA, Ruiz D. Comparison of anticoagulation clinic patient outcomes with outcomes from traditional care in a family medicine clinic. J Am Board Fam Pract 2001;14:16-21. [PubMed: 11206689]

91. Chiquette E, Amato MG, Bussey HI. Comparison of an anticoagulation clinic with usual medical care: anticoagulation control, patient outcomes, and health care costs. Arch Intern Med 1998;158:1641-1647. [PubMed: 9701098]

92. Johnson L. DNA tests to determine warfarin dose. Washington Post The Associated Press. 2007

93. Mathews A. In milestone, FDA pushes genetic tests tied to drug. Wall Street Journal 2007;A1

94. Veenstra DL. The cost-effectiveness of warfarin pharmacogenomics. J Thromb Haemost 2007;5:1974-1975. [PubMed: 17650084] 


\section{Warfarin: Pharmacokinetic \& Pharmacodynamic Pathways}

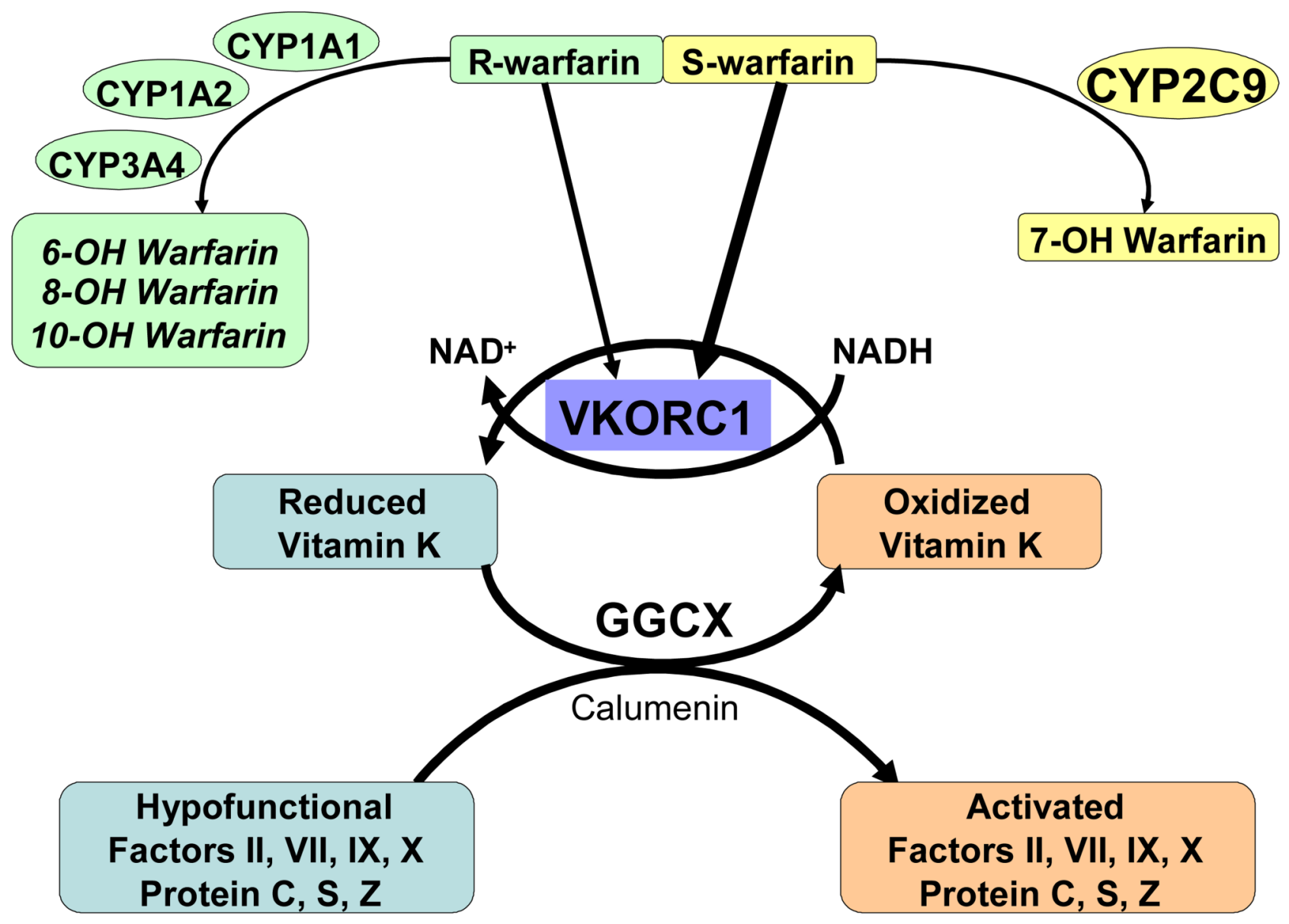

Figure 1.

Warfarin pharmacokinetic and pharmacodynamics pathway. Warfarin is administered as a racemic admixture of $\mathrm{R}$ and $\mathrm{S}$ enantiomers. The more potent $\mathrm{S}$ enantiomer is metabolized principally by Cytochrome P4502C9 (CYP2C9). The pharmacological effect of warfarin is mediated by the inhibition of Vitamin K epoxide reductase complex 1 (VKORC1). This results in the decreased concentrations of activated clotting factors (II, VII, IX and X) producing therapeutic anticoagulation. 


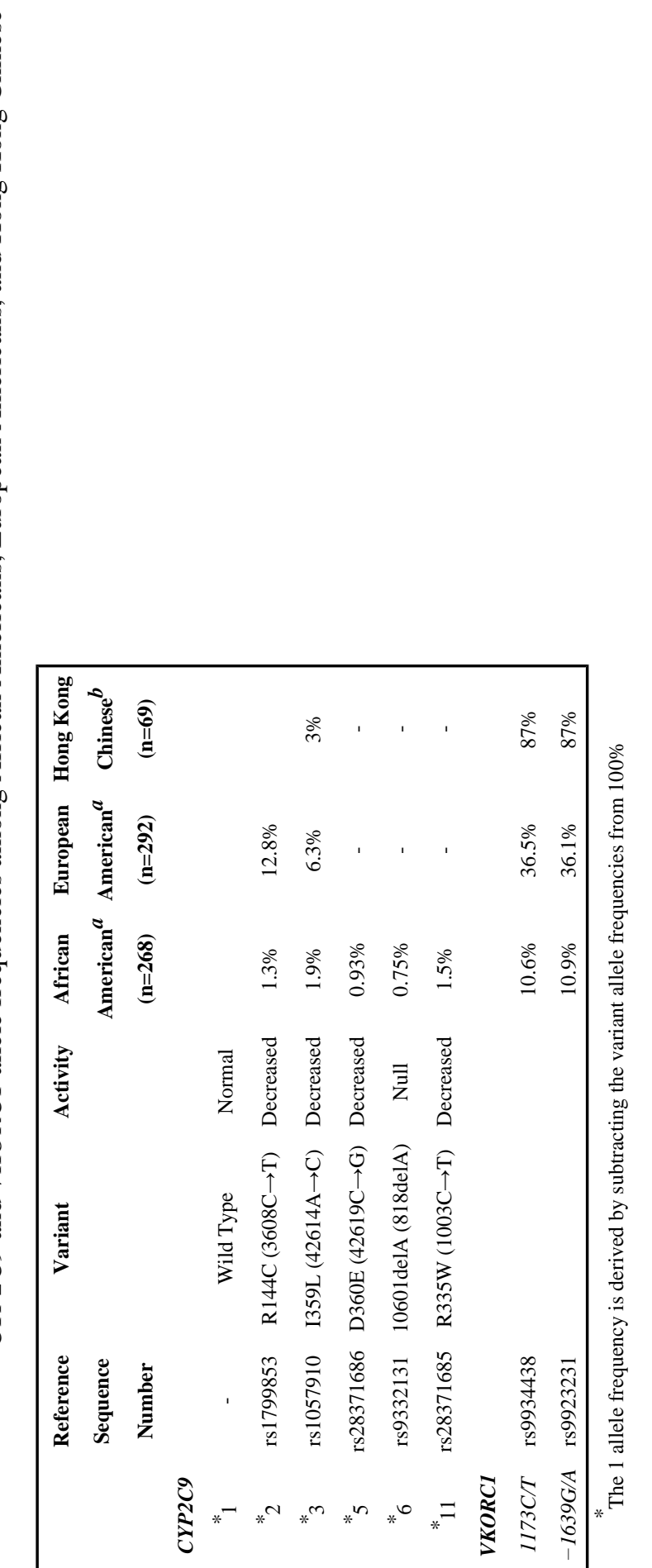




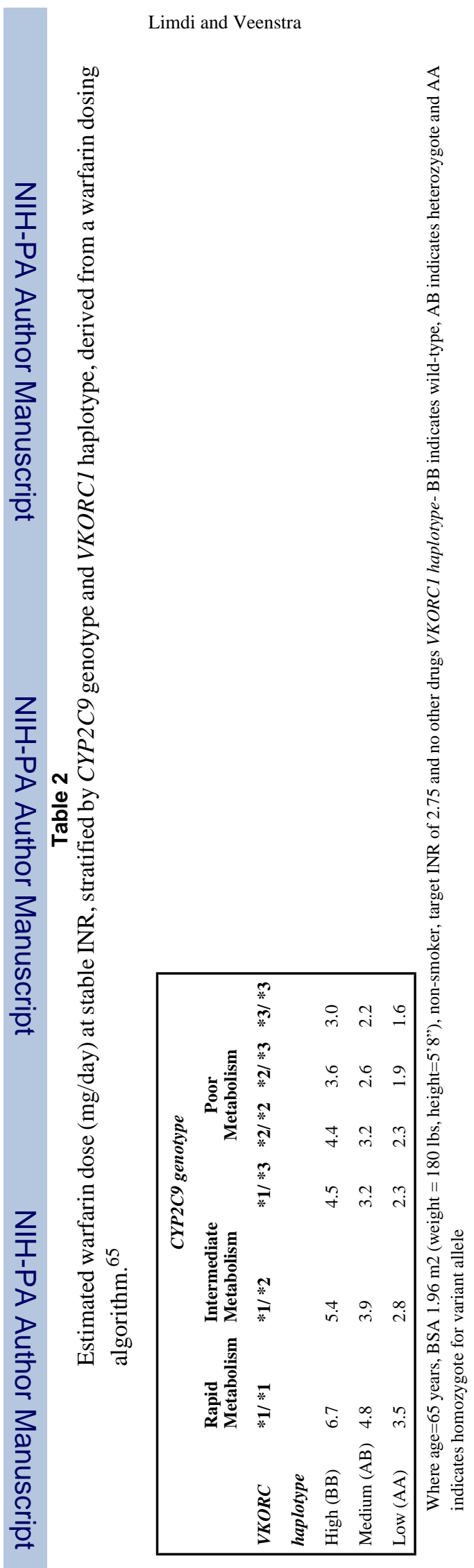

Pharmacotherapy. Author manuscript; available in PMC 2009 October 5. 
Table 3

Selected studies evaluating the influence of $C Y P 2 C 9$ and/ or VKORC1 on attainment and maintenance of target INR among patients on coumarin therapy.

\begin{tabular}{|c|c|c|c|c|}
\hline Study Design & $\begin{array}{l}\text { Polymorphisms } \\
\text { assessed }\end{array}$ & Time to Target INR & Time to Stable INR/ dose & Time in target range \\
\hline${ }^{\infty}$ Retrospective cohort $(\mathrm{n}=561)^{39}$ & CYP $2 C 9 * 2, * 3$ & $\mathrm{NE}$ & $\mathrm{NE}$ & No difference \\
\hline${ }^{x}$ Retrospective Cohort $(\mathrm{n}=186)^{40}$ & CYP $2 C 9 * 2, * 3$ & No difference & $\begin{array}{l}\text { Longer in patients with } \\
\text { variant } C Y P 2 C 9 \text { genotype }\end{array}$ & $\mathrm{NE}$ \\
\hline$\psi_{\text {Prospective cohort }(\mathrm{n}=284)^{74}}$ & CYP2C9 $* 2, * 3$ & $\mathrm{NE}$ & $\begin{array}{l}\text { Longer in patients with } \\
\qquad C Y P 2 C 9 * 2\end{array}$ & $\mathrm{NE}$ \\
\hline$\Phi_{\text {Prospective cohort (n=231) }}{ }^{75}$ & \begin{tabular}{|l|} 
CYP $2 C 9 * 2, * 3$ \\
CYP2C $2 * 3$ allele \\
\end{tabular} & $\mathrm{NE}$ & Longer in patients with & $\mathrm{NE}$ \\
\hline${ }^{\mathrm{x}}$ Nested Case Control $(\mathrm{n}=219)^{73}$ & CYP $2 C 9 * 2, * 3$ & $\mathrm{NE}$ & No difference & No difference \\
\hline$\Phi_{\text {Prospective cohort }(\mathrm{n}=231)^{56}}$ & $\begin{array}{l}\text { CYP2C9 *2, *3 } \\
\text { VKORC1-1173 }\end{array}$ & $\mathrm{NE}$ & $\begin{array}{l}\text { Longer in patients with } \\
\text { CYP2C } 9 * 3 \text { allele }\end{array}$ & $\mathrm{NE}$ \\
\hline$\psi_{\text {Prospective cohort }(\mathrm{n}=281)^{57}}$ & \begin{tabular}{|l} 
CYP $2 C 9 * 2, * 3$ \\
VKORC1-1173 \\
\end{tabular} & $\mathrm{NE}$ & $\begin{array}{l}\text { Longer in patients with } \\
\text { CYP } 2 C 9 * 2\end{array}$ & $\mathrm{NE}$ \\
\hline${ }^{\alpha}$ Prospective cohort $(\mathrm{n}=317,162 \mathrm{AA})^{32}$ & \begin{tabular}{|l|} 
CYP2C9 $* 2, * 3$ \\
VKORC1-1173 \\
\end{tabular} & $\mathrm{NE}$ & No difference & $\mathrm{NE}$ \\
\hline $\begin{array}{l}{ }^{\mathrm{x}} \text { Prospective cohort } \\
(\mathrm{n}=297,29 \text { AA })^{51}\end{array}$ & $\begin{array}{l}\text { CYP } 2 C 9 * 2, * 3 \\
\text { VKORC1-1639, } \\
1173,1542, \\
2255\end{array}$ & $\begin{array}{l}\text { Shorter in patients with } \\
\text { VKORC1 variant }\end{array}$ & $\mathrm{NE}$ & $\begin{array}{l}\mathrm{NE} \\
\text { VKORCl variants spent } \\
\text { more time above range } \\
\quad \text { during initiation }\end{array}$ \\
\hline $\begin{array}{l}{ }^{x} \text { Prospective cohort } \\
(302 \text { EA, } 273 \text { AA })^{24}\end{array}$ & $\begin{array}{l}\text { CYP2C9 } * 2, * 3, \\
* 5, * 6, * 11 \\
\text { VKORC1-1173 }\end{array}$ & $\begin{array}{l}\text { No difference in EA or } \\
\text { AA patients for } \\
\text { CYP2C9 or VKORC1 }\end{array}$ & $\begin{array}{c}\text { No difference in EA or AA } \\
\text { patients for CYP2C9 or } \\
\text { VKORC1 }\end{array}$ & $\mathrm{NE}$ \\
\hline
\end{tabular}

All comparisons are presented for variant versus wild-type genotypes at a non-directional statistical significance of 0.05 .

NE: Not evaluated or not reported, AA: African American; EA: European Americans

Study participations were on different coumarins:

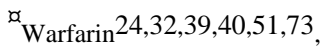

${ }^{\psi}$ Phenprocoumon 57,74 ,

$\Phi$ Acenocoumarol 56,75 
Table 4

Selected studies evaluating the influence of $C Y P 2 C 9$ and / orVKORC1 on risk of over-anticoagulation

\begin{tabular}{|c|c|c|c|c|}
\hline \multirow[t]{2}{*}{ Study Design } & \multirow{2}{*}{$\begin{array}{l}\text { Polymorphisms } \\
\text { Assessed }\end{array}$} & \multicolumn{3}{|c|}{ Risk of over-anticoagulation } \\
\hline & & Definition & \multicolumn{2}{|c|}{ Risk Ratio [95\% CI] } \\
\hline${ }^{x}$ Retrospective cohort $(\mathrm{n}=561)^{39}$ & CYP2C $9 * 2, * 3$ & INR $>8$ & \multicolumn{2}{|c|}{$1.5[0.6,3.6]$} \\
\hline${ }^{x}$ Retrospective Cohort $(n=186)^{40}$ & CYP2C9 $* 2, * 3$ & $\mathrm{INR} \geq 4$ & \multicolumn{2}{|c|}{$1.4[1.03,1.9]$} \\
\hline $\begin{array}{l}\psi \text { Prospective cohort }(n=284) \\
\text { First } 180 \text { days of tx. } 74\end{array}$ & CYP $2 C 9 * 2, * 3$ & INR $>6$ & \multicolumn{2}{|c|}{$3.1[1.6,6.1]$} \\
\hline $\begin{array}{l}\Phi_{\text {Prospective cohort }(\mathrm{n}=231)} \\
\text { First } 180 \text { days of tx. }{ }^{75}\end{array}$ & CYP2C9 $* 2, * 3$ & INR $>6$ & \multicolumn{2}{|c|}{$\begin{array}{l}* 3 \text { allele only } \\
3.8[1.5,9.4]\end{array}$} \\
\hline${ }^{\mathrm{x}}$ Nested Case Control (n=219, first 21 days) ${ }^{73}$ & CYP2C $9 * 2, * 3$ & INR $>3$ & $\begin{array}{l}* 2 \text { allele } \\
* 3 \text { allele }\end{array}$ & $\begin{array}{l}1.8[1.2,2.5] \\
2.2[1.6,3.0]\end{array}$ \\
\hline $\begin{array}{l}\Phi_{\text {Prospective cohort }(\mathrm{n}=231)} \\
\text { First } 180 \text { days of tx. } 56\end{array}$ & $\begin{array}{l}\text { CYP2C9 *2, *3 } \\
\text { VKORC1-1173 }\end{array}$ & INR $>6$ & \multicolumn{2}{|c|}{$\begin{array}{c}\text { Combination of } C Y P 2 C 9 \text { and } V K O R \text { variant } \\
3.8[1.6,9.0]\end{array}$} \\
\hline $\begin{array}{l}\psi_{\text {Prospective cohort }(\mathrm{n}=281)} \\
\text { First } 180 \text { days of tx. } 57\end{array}$ & $\begin{array}{l}\text { CYP } 2 C 9 * 2, * 3 \\
\text { VKORC1-1173 }\end{array}$ & $\mathrm{INR}>6$ & \multicolumn{2}{|c|}{$\begin{array}{c}\text { Combination of } C Y P 2 C 9 \text { and } V K O R \text { variant } \\
7.2[2.1,24.7]\end{array}$} \\
\hline $\begin{array}{l}{ }^{x} \text { Prospective cohort }(\mathrm{n}=317,162 \text { AA) } \\
\text { Prior to stabilization } 32\end{array}$ & $\begin{array}{l}\text { CYP2C9 *2, *3 } \\
\text { VKORC1-1173 }\end{array}$ & $\begin{array}{l}\text { INR }>3 \\
\text { INR }>4\end{array}$ & \multicolumn{2}{|c|}{$\begin{array}{c}\text { European descent only } \\
3.1[1.7,5.5] \\
11.4[1.3,102.0]\end{array}$} \\
\hline${ }^{x}$ Prospective cohort $(\mathrm{n}=297,29 \text { AA })^{51}$ & \begin{tabular}{|l|} 
CYP 2 C $9 * 2, * 3$ \\
VKORC1-1639, \\
1173,1542, \\
2255
\end{tabular} & INR $>4$ & \multicolumn{2}{|c|}{$\begin{array}{c}\text { CYP } 2 C 9 * 1 / * 2, * 1 / * 3: \\
1.6[1.0,2.6] \\
* 2 / * 2, * 2 / * 3, * 3 / * 3: \\
2.5[0.9,6.5] \\
\text { VKORC1 } A / \text { non-A: } 2.2[1.4,3.6] \\
\text { A/A } 2.5[1.3,5.0]\end{array}$} \\
\hline${ }^{\mathrm{x}}$ Prospective cohort (302 EA, $\left.273 \mathrm{AA}\right)^{24}$ & $\begin{array}{l}\text { CYP } 2 C 9 * 2, * 3, \\
* 5, * 6, * 11 \\
\text { VKORC1-1173 }\end{array}$ & $\mathrm{INR}>4$ & \multicolumn{2}{|c|}{$\begin{array}{c}\text { European descent only } \\
\text { First } 30 \text { days } \\
\text { VKORC1: } 3.75(1.52,9.30) \\
\text { CYP2C } 9: 2.84(0.91,8.85) \\
\text { Prior to stabilization } \\
\text { VKORC1: } 2.69(1.32,5.47) \\
\text { CYP2C9: } 2.69(1.32,5.47) \\
\text { Duration of therapy } \\
\text { VKORC1: } 1.91(1.27,2.89) \\
\text { CYP2C9: } 1.82(0.97,3.43)\end{array}$} \\
\hline
\end{tabular}

All comparisons are presented for variant versus wild-type genotypes at a non-directional statistical significance of 0.05 .

AA: African American, EA: European American

Study participations were on different coumarins

${ }^{\ltimes}$ Warfarin $24,32,39,40,51,73$

${ }^{\psi}$ Phenprocoumon 57,74 ,

$\Phi$ Acenocoumarol 56,75 
Table 5

Selected studies evaluating the influence of $C Y P 2 C 9$ and / orVKORC1 on risk of hemorrhage

\begin{tabular}{|c|c|c|c|}
\hline \multirow[t]{2}{*}{ Study Design } & \multirow{2}{*}{$\begin{array}{l}\text { Polymorphisms } \\
\text { Assessed }\end{array}$} & \multicolumn{2}{|c|}{ Risk of Hemorrhage } \\
\hline & & Minor & Major \\
\hline $\begin{array}{l}\text { Case Control } \\
(36 \text { cases, } 52 \text { controls) } 82\end{array}$ & CYP $2 C 9 * 2, * 3$ & $2.7[0.9,8.1]$ & $3.7[1.4,9.5]$ \\
\hline $\begin{array}{l}\text { Retrospective cohort } \\
(\mathrm{n}=180)^{38}\end{array}$ & CYP $2 C 9 * 2, * 3$ & \multicolumn{2}{|c|}{$\begin{array}{c}\text { Minor and Major Combined } \\
2.6[1.2,5.7] \\
\end{array}$} \\
\hline $\begin{array}{l}\text { Retrospective Cohort } \\
(\mathrm{n}=186)^{40}\end{array}$ & CYP $2 C 9 * 2, * 3$ & $\mathrm{NE}$ & $2.4[1.2,4.9]$ \\
\hline $\begin{array}{l}\text { Prospective cohort } \\
(n=446,227 \text { AA })^{36}\end{array}$ & $\begin{array}{l}\text { CYP2C9 *2, *3 } \\
\text { VKORC1-1173 }\end{array}$ & $\begin{array}{c}\text { CYP2C9 } \\
1.3[0.8,1.9] \\
\text { VKORC1 } \\
0.8[0.5,1.3]\end{array}$ & $\begin{array}{c}\text { CYP2C9 } \\
3.0[1.2,7.5] \\
\text { VKORC1 } \\
1.7[0.7,4.4] \\
\end{array}$ \\
\hline
\end{tabular}

Study participants were on warfarin $36,38,40,82$

All comparisons are presented for variant versus wild-type genotypes at a non-directional statistical significance of 0.05 .

NE - not evaluated or not reported.

AA: African American.

Minor hemorrhage included mild nosebleeds, microscopic hematuria, mild bruising, and mild hemorrhoidal bleeding. Major hemorrhage combined serious, life-threatening and fatal bleeding episodes as defined by Fihn et al. ${ }^{83}$ 
Table 6

Randomized studies comparing genotype based warfarin therapy (Target INR 2-3) to standard medical care in assessing warfarin response

\begin{tabular}{|c|c|c|}
\hline & Caraco et al, $2007^{a}$ & Anderson et al, $2007 b$ \\
\hline \multicolumn{3}{|l|}{ Population Characteristics } \\
\hline Number of subjects evaluated & 191 (95 PG, 96 STD) $\Phi$ & 200 (101 PG, 99 STD $)^{\Phi}$ \\
\hline Racial/ Ethnic Group & $100 \%$ European descent & 95\% European descent \\
\hline \multicolumn{3}{|l|}{ Study Characteristics } \\
\hline Follow- up (Mean \pm SD) & Different in two arms & $46 \pm 32$ days \\
\hline INR assessment schedule & $\begin{array}{l}\text { Daily until target INR is } \\
\text { sustained for } 2 \text { days then } \\
\text { at least twice weekly } \\
\text { until stabilized }\end{array}$ & $\begin{array}{l}\text { Days } 0,3,5,8,21,60,90 \text {, } \\
\text { and as clinically indicated }\end{array}$ \\
\hline \multicolumn{3}{|l|}{ Polymorphisms assessed } \\
\hline$C Y P 2 C 9$ & $* 2, * 3$ & $* 2, * 3$ \\
\hline VKORC1 & $\mathrm{NE}$ & $1173 C / T$ \\
\hline \multicolumn{3}{|l|}{ Genotype guided therapy: } \\
\hline Improved dose prediction & $\mathrm{NE}$ & Yes, $\mathrm{p}<0.001$ \\
\hline $\begin{array}{r}\% \text { Variance in dose predicted by genes } \\
\text { (genes + clinical covariates) }\end{array}$ & $\mathrm{NE}$ & $32 \%(47 \%)$ \\
\hline$\downarrow$ number of dose changes & $\mathrm{NE}$ & $\begin{array}{l}\text { Yes, however follow-up } \\
\text { duration and indication } \\
\text { differed across groups }\end{array}$ \\
\hline$\downarrow$ INR monitoring frequency & Yes & $\begin{array}{l}\text { Yes, however follow-up } \\
\text { duration and indication } \\
\text { differed across groups }\end{array}$ \\
\hline Influenced time to target INR & $\begin{array}{l}\text { PG attained target INR } \\
\text { sooner }\end{array}$ & No \\
\hline Influenced time to stable dose & $\begin{array}{l}\text { PG attained stable INR } \\
\text { sooner }\end{array}$ & No \\
\hline$\downarrow$ out-of-range INRs & Yes $(<1.8$ or $>3.4)$ & No $(<1.8$ or $>3.2) \oplus$ \\
\hline$\uparrow$ Time in target range & Higher in $\mathrm{PG}$ group $\oplus$ & No \\
\hline$\downarrow$ risk of over-anticoagulation & Yes & No \\
\hline$\downarrow$ risk of complications $\psi$ & For Minor bleed, $\mathrm{p}<0.02$ & $\mathrm{NE}$ \\
\hline
\end{tabular}

Anderson et al defined Stable dose as dose (after day 8) that was associated with $\geq 2$ (within $15 \%$ ) INRs in target range measured $\geq 1$ week apart. Caraco et al defined stable dose as the dose associated with $\geq 2$ INRs in target range, measured $\geq 1$ week apart.

$\oplus_{\text {Primary Endpoint }}$

NE: Not evaluated or not reported

${ }^{\psi}$ Although all studies defined adverse event as a composite endpoint including INR $\geq 4$, major (and minor) hemorrhage and recurrent thromboembolic event, the cohort size and follow-up duration did not facilitate evaluation of hemorrhagic or thromboembolic complications.

$a_{\text {Caraco et al }} 87$

${ }^{b}$ Anderson et al 88 